\title{
Assessment of the ability DS-EIA-HIV-AB-TERM assay correctly identify long-standing and recent HIV infection
}

\author{
YE Zagryadskayaa ${ }^{1 *}$, VF Puzyrev ${ }^{1}$, AN Burkov ${ }^{1}$, DA Neshumaev ${ }^{3}$, TI Ulanova ${ }^{1,2}$, Irina Sharipova ${ }^{1}$ \\ From Abstracts from International Symposium HIV and Emerging Infectious Diseases 2014 \\ Marseille, France. 21-23 May 2013
}

\section{Background}

The assessment of newly acquired human immunodeficiency virus type 1 (HIV-1) infection, or incidence, provides important information for public health programs and is crucial for understanding the status of the epidemic and providing information regarding the impact of prevention measures. The aim of this study was to evaluate the ability of the assay DS-EIA-HIV-AB-TERM correctly identify long-standing and recent HIV infection in samples with the preliminary defined time of HIV-1 infection.

\section{Materials and methods}

The assay DS-EIA-HIV-AB-TERM intended for the identification of recently acquired HIV-1 infection was used in the study. Efficiency assessment of the test was carried out using serum samples $(n=239)$ with the preliminary defined time of HIV-1 infection which was identified based on HIV algorithm testing: recent infection samples $(n=150)$, long-standing infection ( $\mathrm{n}=89$, including samples with a low CD4+ T cell count) ("Krasnoyarsk Regional center of AIDS prevention", "Nizhny Novgorod Regional center of AIDS prevention", Russia). Additionally the assay assessment was carried out using seroconversion panels $(n=32)$ (SeraCare, ZeptoMetrix, USA).

\section{Results}

The assay is able to define as recent infection $100 \%$ of samples with seroconversion profile. Among samples with the preliminary defined time of HIV infection the accuracy of testing was: $93.3 \%$ - for recent (up to 9 months), $97.8 \%$ - for long-standing infection (9 month

${ }^{1}$ RPC "Diagnostic Systems", Nizhny Novgorod, Russia

Full list of author information is available at the end of the article and more). All serum samples with late-stage infection (low CD4+ T cell count) were determined correctly.

\section{Conclusion}

Our data demonstrated high efficiency of the kit DSEIA-HIV-AB-TERM to identify both recently acquired and long-standing infection among samples from HIV type 1 seropositive persons.

\section{Authors' details}

'RPC "Diagnostic Systems", Nizhny Novgorod, Russia. 'DSI S.r.l. Saronno (VA), Italy. "Krasnoyarsk Regional Center of AIDS Prevention, Krasnoyarsk, Russia.

Published: 23 May 2014

doi:10.1186/1471-2334-14-S2-P70

Cite this article as: Zagryadskaya et al:: Assessment of the ability DS-EIA-HIV-AB-TERM assay correctly identify long-standing and recent HIV infection. BMC Infectious Diseases 2014 14(Suppl 2):P70.

Submit your next manuscript to BioMed Central and take full advantage of:

- Convenient online submission

- Thorough peer review

- No space constraints or color figure charges

- Immediate publication on acceptance

- Inclusion in PubMed, CAS, Scopus and Google Scholar

- Research which is freely available for redistribution 